\title{
Primjena naprednih polimernih materijala
}

\section{Gilja, Z. Katančić, Lj. Kratofil Krehula, A. Peršić i Z. Hrnjak-Murgić*}

Zavod za polimerno inženjerstvo i organsku kemijsku tehnologiju, Fakultet kemijskog inženjerstva i tehnologije, Sveučilište u Zagrebu, Marulićev trg 19, 10000 Zagreb

\begin{abstract}
Sažetak limernih nanokompozita s ciljem modifikacije navedenih svojstava.

\author{
Ključne riječi \\ uV blokatori, usporivači gorenja, fotokatalizatori
}

Napredni polimerni materijali, polimerni (nano)kompoziti, antimikrobna aktivnost,
\end{abstract}

Sve intenzivniji razvoj naprednih polimernih materijala kao što su polimerne mješavine i (nano)kompoziti nude brojna inovativna rješenja za različitu upotrebu, što ima velik ekonomski značaj za plastičnu industriju i područja u kojima se primjenjuju. Napredne tehnike modificiranja polimera razvile su se gotovo do krajnjih granica, a znatno su poboljšale omjer troškova i svojstava nastalih modifikacijom strukture polimera. Miješanje različitih polimera, priprema (nano)kompozita te stvaranje višeslojnih materijala, laminata neke su od najznačajnijih tehnika modifikacije. Pri tome postoje sinergistička djelovanja između komponenti, kako bi se postigli izvrsni učinci koji su prilagođeni specifičnim primjenama, kao npr. antimikrobno djelovanje, blokiranje ultraljubičastog svjetla, smanjenje gorivosti, fotokatalitičko djelovanje, a u radu su prikazani rezultati ispitivanja po-

\section{Uvod}

Polimerni materijali primjenjuju se zbog brojnih prednosti u odnosu na konvencionalne materijale (metal, drvo, staklo), pa su tako zbog niske gustoće lagani, visoke su čvrstoće i fleksibilnosti, visoke dimenzijske stabilnosti, nižih svojstava toplinskog širenja i zamora, otporni su na lom, imaju dobru kemijsku postojanost, lako se prerađuju i relativno su niske cijene. Polimeri su vrlo široka klasa materijala koji su našli primjenu u mnogim područjima, od avioindustrije preko biomedicinskih primjena, sustava za dostavu lijekova, biosenzorskih uređaja, tkivnog inženjerstva, kozmetike itd. U posljednjih nekoliko desetljeća napredne tehnike modificiranja polimera omogućile su razvoj naprednih polimernih materijala miješanjem punila različitih veličina (mikro-, nano-) i oblika (čestice, vlakna, cijevi), što je doprinijelo razvoju novih svojstava. Danas se za razvoj suvremenih tehnologija i njihovu učinkovitu primjenu upotrebljavaju inovativni polimerni materijali s točno određenim, specifičnim svojstvima. Takve nove primjene su: pametni i visoko učinkoviti premazi, ambalaža visoko barijernih svojstava, akumuliranje solarne energije, polimerni senzori, elektrovodljivi polimeri, membrane za transport plina, pametni sustavi za isporuku lijekova $\mathrm{i} d r$.

\section{Napredni polimerni materijali}

\subsection{Polimerni nanokompoziti s antimikrobnim i UV blokirajućim djelovanjem}

Nanokompoziti poli(vinil klorida)/titanijeva dioksida (PVC/ $\mathrm{TiO}_{2}$ ) s dodatkom i bez dodatka srebrova nitrata $\left(\mathrm{AgNO}_{3}\right) \mathrm{i}$

*Autor za dopisivanje: prof. dr. sc. Zlata Hrnjak-Murgić, e-pošta: zhrnjak@fkit.hr bakrova nitrata $\left(\mathrm{Cu}\left(\mathrm{NO}_{3}\right)_{2}\right)$ pripremljeni su te karakterizirani prema proceduri detaljno opisanoj u prethodnom radu. ${ }^{1}$ Ispitana je postojanost na djelovanje mikroorganizama, UV blokirajuće djelovanje i mehanička svojstva.

Ispitivanje antimikrobne djelotvornosti nanokompozita $\mathrm{PVC} / \mathrm{TiO}_{2}$ provedeno je metodom difuzije gdje se promatrao promjer oko diska polimernog materijala na hranjivoj podlozi u Petrijevoj zdjelici u kojem nisu narasle bakterije. Sto je veći prsten oko uzorka diska, veća je antimikrobna aktivnost. Dobiveni rezultati pokazuju da je do najmanjeg rasta bakterija oko uzorka diska došlo kod uzorka PVC/TiO ${ }_{2}: \mathrm{AgNO}_{3}=1: 10$ (slika 1), iz čega se može zaključiti da taj uzorak pokazuje najveće antimikrobno djelovanje. Antimikrobna aktivnost srebra temelji se na činjenici da srebro na bakterijskim stanicama uzrokuje strukturne i funkcionalne defekte jer razara staničnu stjenku, prodire unutar stanice te zatim uzrokuje defekte na bakterijskoj DNA, što u konačnici izaziva inhibiciju staničnih funkcija i smrt bakterijske stanice. Kao antimikrobne tvari mogu se upotrebljavati različiti metalni oksidi poput $\mathrm{ZnO}_{\text {i TiO}}$, no
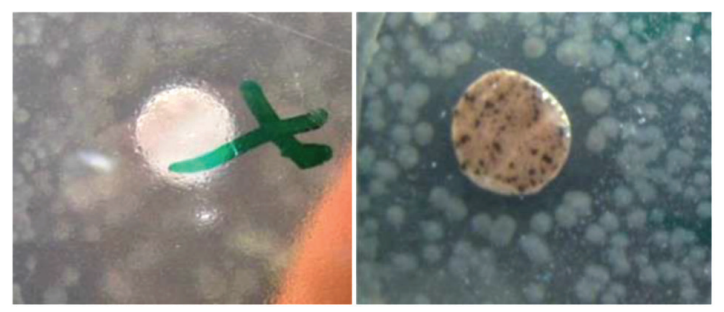

Slika 1 - Antimikrobna aktivnost uzorka čistog PVC-a te nanokompozita $\mathrm{PVC} / \mathrm{TiO}_{2}: \mathrm{AgNO}_{3}=1: 10$

Fig. 1 - Antimicrobial activity of pure PVC and PVC nanocomposite $\mathrm{PVC} / \mathrm{TiO}_{2}: \mathrm{AgNO}_{3}=1: 10$ 
uz dodatak srebra i zlata povećava im se antimikrobno djelovanje. ${ }^{2-4}$ Svojstvo povećane otpornosti prema rastu mikroorganizama vrlo je značajno kada se polimerni materijali upotrebljavaju za pakiranje namirnica ili se primjenjuju u medicini i farmaciji.

Na slici 2 prikazani su UV/Vis spektri uzoraka PVC nanokompozitnih filmova koji pokazuju povećanje apsorbancije u UV području u odnosu na čisti PVC i to u UV-A području (315 - $400 \mathrm{~nm})$. Nadalje, važno je primijetiti da uzorci PVC/TiO $2: \mathrm{AgNO}_{3}=1: 10 \mathrm{i}$ $\mathrm{PVC} / \mathrm{TiO}_{2}+\mathrm{AgNO}_{3}+\mathrm{Cu}\left(\mathrm{NO}_{3}\right)_{2}$ pokazuju apsorbanciju i u vidljivom dijelu spektra (400 - $800 \mathrm{~nm}$ ). Dakle, dokazana je povećana apsorpcijska moć $\mathrm{TiO}_{2}$ modificiranog srebrom i kombinacijom srebra i bakra. Svojstvo povećane otpornosti materijala na UV i vidljivo zračenje važno je kada se polimerni materijali upotrebljavaju kao ambalažni materijali, čime se materijal štiti od degradacije tijekom stajanja na policama te tijekom transporta. ${ }^{5}$

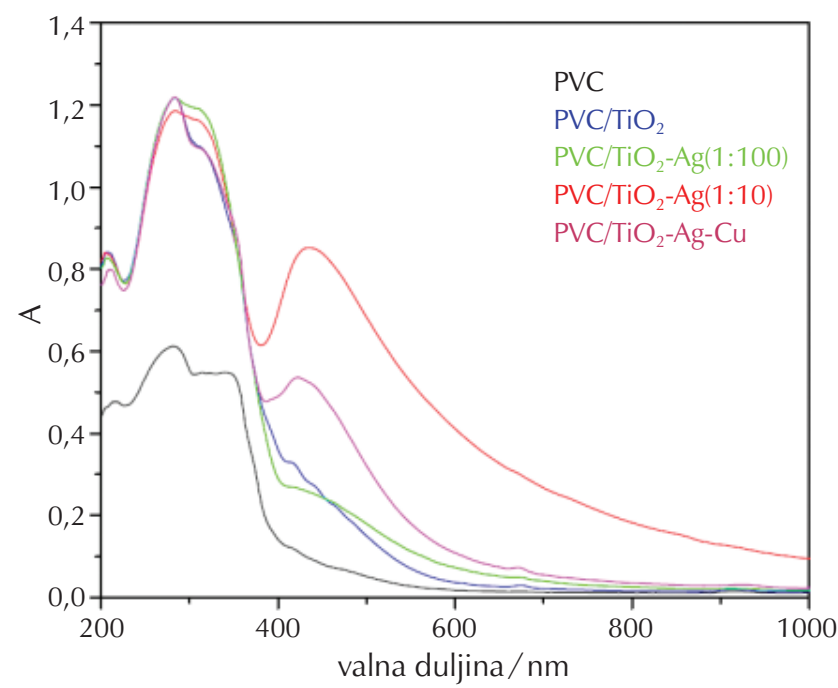

Slika 2 - UV/Vis spektri PVC-a i uzoraka PVC nanokompozita Fig. 2 - UV/Vis spectra of PVC and PVC nanocomposite films

Uzorcima PVC nanokompozitnih filmova određena je prekidna čvrstoća $(\sigma)$ i prekidno istezanje $(\varepsilon)$. Rezultati su prikazani u tablici 1 . Kod polimernih nanokompozita važ- no je da se mehanička svojstva ne narušavaju dodatkom punila u odnosu na polazne komponente, tj. čisti materijal. Rezultati pokazuju da kod pripremljenih nanokompozita ne dolazi do narušavanja mehaničkih svojstava, osim za uzorak pripremljen s dodatkom bakrova nitrata. Razlog tome vjerojatno je nehomogeno dispergiranje čestica, zbog čega nastaju agregati koji predstavljaju mjesta potencijalnih defekata u materijalu. Ukoliko se uspostave interakcije između komponenata, punilo se u polimernoj matrici homogeno dispergira i ne dolazi do narušavanja mehaničkih svojstava. Iz rezultata prikazanih u tablici 1 vidljivo je da utjecaj dodatka punila u polimernu matricu nije uzrokovao značajan pad čvrstoće, dok je istezanje u nekim slučajevima i značajno povećano. Jedina iznimka je uzorak koji sadrži kombinaciju Ag i Cu nitrata gdje dolazi do značajnog pada mehaničkih svojstava.

Tablica 1 - Mehanička svojstva PVC nanokompozita

Table 1 - Mechanical properties of PVC nanocomposites

\begin{tabular}{c|c|c}
\hline Uzorak & $\sigma / \mathrm{Nmm}^{-2}$ & $\varepsilon / \%$ \\
\hline $\mathrm{PVC}$ & 10,3 & 143,6 \\
\hline $\mathrm{PVC} / \mathrm{TiO}_{2}$ & 8,6 & 149,3 \\
\hline $\mathrm{PVC} / \mathrm{TiO}_{2}: \mathrm{AgNO}_{3}=1: 100$ & 13,1 & 205,4 \\
\hline $\mathrm{PVC} / \mathrm{TiO}_{2}: \mathrm{AgNO}_{3}=1: 10$ & 8,3 & 171,0 \\
\hline $\mathrm{PVC} / \mathrm{TiO}_{2}+\mathrm{AgNO}_{3}+\mathrm{Cu}\left(\mathrm{NO}_{3}\right)_{2}$ & 3,1 & 9,8 \\
\hline
\end{tabular}

Nadalje, iz rezultata termogravimetrijske analize vidljivo je da dodane tvari u polimernu PVC matricu mogu djelovati i na mehanizam toplinske razgradnje. Uzorci PVC nanokompozita pokazuju izmjenu toplinske stabilnosti u odnosu na čisti PVC, tj. imaju povećanu vrijednost $T_{95}$, a kod uzorka s dodanim $\mathrm{AgNO}_{3}$ u omjeru 1 : 10 dolazi i do značajnog povećanja ostatka nakon pirolize, što ukazuje na povećanu početnu toplinsku stabilnost, tablica 2.

\subsection{Polimerni nanokompoziti s fotokatalitičkim djelovanjem}

Vodljivi polimeri vrlo su zanimljivi zbog svojih svojstava te široke mogućnosti primjene kao što su baterije, senzori,

Tablica 2 - Rezultati termogravimetrijske analize PVC nanokompozita

Table 2 - Results of thermogravimetric analysis of PVC nanocomposites

\begin{tabular}{c|c|c|c|c|c}
\hline Uzorak & $T_{95} /{ }^{\circ} \mathrm{C}$ & $T_{\max 1} /{ }^{\circ} \mathrm{C}$ & $T_{\max 2} /{ }^{\circ} \mathrm{C}$ & Ostatak $/ \%$ & $r_{\max } / \% \min ^{-1}$ \\
\hline $\mathrm{PVC}$ & 227 & 267 & 452 & 42,6 & 20 \\
\hline $\mathrm{PVC} / \mathrm{TiO}_{2}$ & 238 & 271 & 448 & 39,6 & 24 \\
\hline $\mathrm{PVC} / \mathrm{TiO}_{2}: \mathrm{AgNO}_{3}=1: 10$ & 235 & 264 & - & 49,9 & 31 \\
\hline $\mathrm{PVC} / \mathrm{TiO}_{2}: \mathrm{AgNO}_{3}=1: 100$ & 234 & 264 & 451 & 40,1 & 37 \\
\hline $\mathrm{PVC} / \mathrm{TiO}_{2}+\mathrm{AgNO}_{3}+\mathrm{Cu}\left(\mathrm{NO}_{3}\right)_{2}$ & 233 & 259 & 461 & 30,9 & 12 \\
\hline
\end{tabular}


"pametni" tekstilni materijali, "pametni" sustavi za isporuku lijekova, fotokatalizatori za pročišćavanje otpadnih voda i $\mathrm{dr}^{6}{ }^{6}$ Potencijal upotrebe vodljivih polimera u fotokatalitičkim postupcima obrade vode prepoznat je kao jedno od zanimljivih i učinkovitih, ali za sada nedovoljno istraženih područja. $U$ postupcima pročišćavanja vode ispitivane su ionske izmjene i adsorpcijski kapaciteti vodljivih polimera s ciljem omekšavanja vode, uklanjanja različitih aniona i organskih onečišćivala. Međutim, materijali koji su se pokazali kao izvrsni fotokatalizatori su poluvodiči. Prednost upotrebe metalnih oksida kao poluvodičkih fotokatalizatora, u usporedbi s konvencionalnim metodama pročišćavanja voda, pruža mogućnost potpune mineralizacije onečišćenja bez upotrebe dodatnih kemikalija, što je vrlo poželjno s ekološkog i ekonomskog stajališta. Stoga je sve veći interes za pripremu i razvoj poluvodičkih materijala koji će biti aktivni ne samo u UV području Sunčeva svjetla nego i u vidljivom. Pomicanje aktivnosti fotokatalizatora i u vidljivo područje zračenja, nižih energija a većih valnih duljina, postiže se pripremom nanokompozitnih fotokatalizatora na bazi vodljivih polimera (polianilin (PANI), polipirol (PPy). ${ }^{7}$

Zbog sinergijskog međudjelovanja komponenti koje čine polimerni kompozit, postižu se bolja mehanička svojstva, kemijska otpornost, toplinska postojanost te električna i optička aktivnost u usporedbi s čistim polimerom. Stoga, određivanje i poznavanje optimalnih uvjeta sinteze kao što su koncentracija monomera i oksidansa, koncentracija monomera i fotokatalizatora, vrsta oksidansa, pH vrijednost, temperatura i duljina trajanja sinteze vrlo su važni parametri za sintezu polimernih nanokompozita s fotokatalitičkim djelovanjem. ${ }^{8}$

Sinteza vodljivih polimernih nanokompozita kemijskom oksidacijskom polimerizacijom provedena je in situ uz dodatak nanočestica fotokatalizatora $\left(\mathrm{TiO}_{2}\right)$. Najčešće upotrijebljeni oksidansi su amonijev persulfat $\left(\left(\mathrm{NH}_{4}\right)_{2} \mathrm{~S}_{2} \mathrm{O}_{8}\right)$, vodikov peroksid $\left(\mathrm{H}_{2} \mathrm{O}_{2}\right)$, željezov(III) klorid $\left(\mathrm{FeCl}_{3}\right)$, kalijev dikromat $\left(\mathrm{K}_{2} \mathrm{Cr}_{2} \mathrm{O}_{7}\right)$ i dr. Prilikom sinteze vodljivih polimernih nanokompozita promjenu oksidacijskog stanja i električne provodnosti jednostavno je uočiti i pratiti na temelju promjene boje materijala, a navedena pojava naziva se elektrokromizam. Mnogi organski i anorganski materijali pokazuju elektrokromatska svojstva uključujući i vodljive polimere. Polianilin u poluoksidiranom stanju (emeraldin) zelene je boje, a ukoliko se oksidira, prelazi u pernigranilin koji je ljubičastoplav. Fotoaktivnost te oksidacijsko stanje polimernih kompozitnih materijala može se pratiti pomoću UV/Vis spektroskopije. ${ }^{9}$ Na slici 3 prikazani su spektri uzoraka PPy/TiO ${ }_{2}$ nanokompozita s dva široka maksimuma u području UV zračenja koji se odnose na fotoaktivnost $\mathrm{TiO}_{2}$ i vidljivog dijela zračenja između 480 i 750 nm koji se odnose na fotoaktivnost vodljivog PPy polimera. Vrpce koje se javljaju u tom području odnose se na dopirani PPy koji je posljedica prisutnih polarona i bipolarona.

Interakcije između dopiranog $\mathrm{PPy}$ i $\mathrm{TiO}_{2}$ katalizatora $\mathrm{u}$ obliku $\mathrm{N}_{-\mathrm{Ti}^{2+}}$ utjecale su na pomicanja aktivnosti fotokatalizatora iz UV i u vidljivi dio spektra. Može se primijetiti da se apsorbancija u vidljivom dijelu spektra povećava s

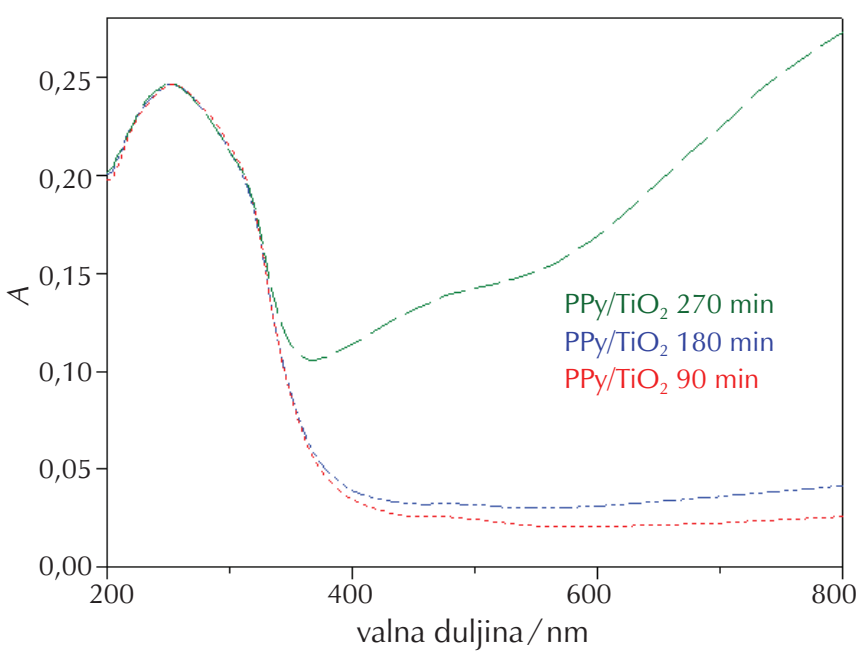

Slika 3 - UV/Vis spektri PPy/TiO 2 nanokompozita sintetiziranih u trajanju od 90, 180 i $270 \mathrm{~min}$

Fig. 3 - UV/Vis spectra of $\mathrm{PPy} / \mathrm{TiO}_{2}$ nanocomposites synthesised for 90,180 , and $270 \mathrm{~min}$

produljenim vremenom trajanja sinteze, a posljedica je većeg sadržaja polipirola u kompozitu odnosno na površini $\mathrm{TiO}_{2}$. Osim duljine trajanja sinteze udio vodljivog polimera u kompozitu također uvelike utječe na oblik $i$ veličinu sintetiziranih polimernih lanaca, strukturu materijala, a posljedično tome na svojstva i primjenu dobivenog nanokompozita. Pripremljeni su $\mathrm{PANI} / \mathrm{TiO}_{2}$ nanokompozitni fotokatalizatori s različitim udjelom vodljivog polimera polianilina te im je termogravimetrijskom analizom ispitana toplinska postojanost. ${ }^{10}$ Razlike u toplinskoj stabilnosti pripremljenih uzoraka mogu se pripisati različitoj strukturi i veličini polimernih lanaca polianilina tijekom polimerizacije te različitim mehanizmima toplinske razgradnje kompozita a vidljive su na slici 4 .

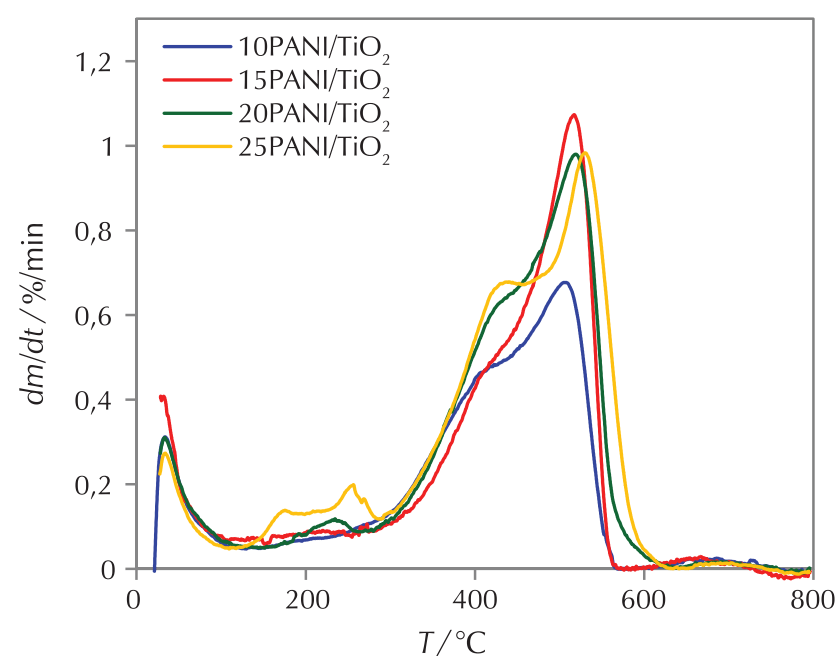

Slika 4 - dTG krivulje sintetiziranih PANI/TiO 2 nanokompozita Fig. 4 - dTG curve of synthesised $\mathrm{PANI} / \mathrm{TiO}_{2}$ nanocomposites 


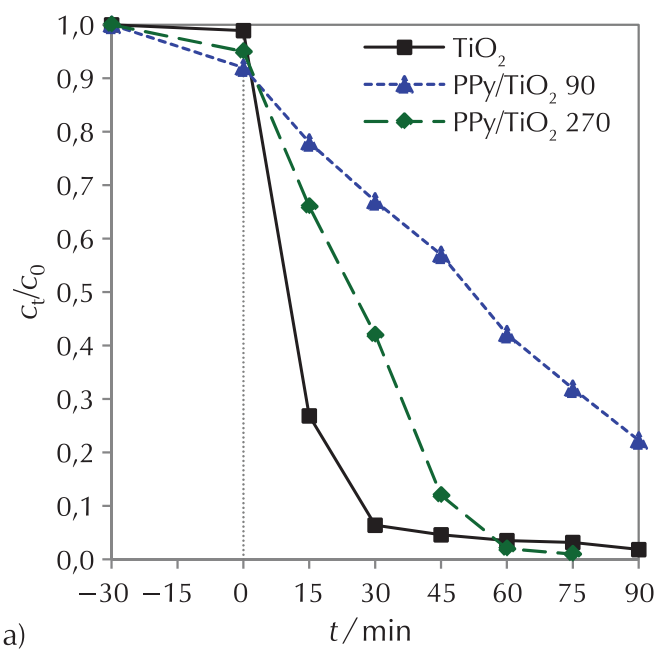

a)

Slika 5 - Fotokatalitička razgradnja RR45 bojila pomoću PPy/TiO ${ }_{2}$ fotokatalizatora pri a) UVA i b) simuliranom Sunčevu zračenju ( $\gamma_{\text {kat }}=1 \mathrm{~g} \mathrm{dm}^{-3}, \gamma_{\mathrm{RR} 45}=30 \mathrm{mg} \mathrm{dm}^{-3}, \mathrm{pH}=6,6$ )

Fig. 5 - Photocatalytic degradation of RR45 dye with $\mathrm{PPy} / \mathrm{TiO}_{2}$ photocatalyst under a) UVA and b) simulated solar irradiation $\left(\gamma_{\mathrm{kat}}=1 \mathrm{~g} \mathrm{dm}^{-3}, \gamma_{\mathrm{RR} 45}=30 \mathrm{mg} \mathrm{dm}^{-3}, \mathrm{pH}=6.6\right.$ )

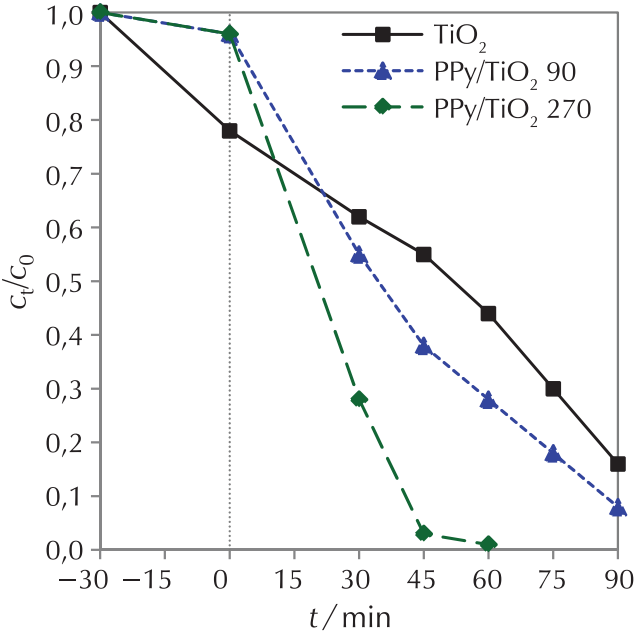

Iz rezultata termogravimetrijske analize može se vidjeti da se razgradnja kompozita odvija u tri stupnja. Prvi stupanj odnosi se na gubitak zaostale vode, drugi ukazuje na uklanjanje dopanta, oligomera i nečistoća, a treći karakterizira razgradnju PANI polimernog lanca. Može se zaključiti da se PANI polimerni lanci niže molekulske mase razgrađuju u drugom temperaturnom području, dok polimerni lanci viših molarnih masa ukazuju na veću toplinsku stabilnost te se naknadno razgrađuju.

Upotrebom vodljivih polimera u pripremi polimernih nanokompozita dolazi do oblaganja čestica fotokatalizatora vodljivim polimerom, pri čemu nastaju barijere koje sprječavaju agregaciju nanočestica. Na proces agregacije čestica također može utjecati vrijednost $\mathrm{pH}$ otopine tijekom sinteze kompozita. Oksidacijom anilina u kiselom mediju $(\mathrm{pH}<2,5)$ mogu nastati različite strukture kao što su granule, ploče, oligomeri ili disperzije čistog polimera u otopini, kojima, ovisno o stupnju oksidacije i dopiranju, varira električna provodnost. ${ }^{11}$ Uobičajena provodnost dopiranih vodljivih polimera nalazi se u rasponu $10^{-6}-10^{3} \mathrm{~S} \mathrm{~cm}^{-1}$, dok se provodnost konjugiranih polimera bez dopiranja kreće u rasponu $10^{-9}-10^{-7} \mathrm{~S} \mathrm{~cm}^{-1}$. Električna provodnost vodljivih polimera raste s povećanjem koncentracije monomera zbog većeg broja ponavljajućih konjugiranih jedinica unutar molekule polimera. Jake interakcije fotokatalizatora i vodljivih polimera te konjugirana struktura i električna provodnost omogućuju aktivaciju fotokatalizatora u vidljivom dijelu Sunčeva zračenja. Ispitivanje fotokatalitičke djelotvornosti, tj. fotoaktivnosti pripremljenih polimernih nanokompozitnih fotokatalizatora provodi se razgradnjom onečišćenja djelovanjem UV i simuliranog Sunčeva zračenja. Ukoliko se polimerni kompozit izloži Sunčevu zračenju, vodljivi polimer apsorbira foton svjetla i započinje prijenos elektrona iz valentne u vodljivu vrpcu polimera. Nakon toga elektroni iz vodljive vrpce polimera prelaze u vodljivu vrpcu katalizatora $\left(\mathrm{TiO}_{2}\right)$, pri čemu dolazi do njegove aktivacije, a potom se nastavlja proces fotokatalitičke razgradnje onečišćenja u vodi. Nastaju parovi elektron-šupljina koji reagiraju s vodom i nastaju hidroksilni $\left(\mathrm{OH}^{*}\right)$ i superoksidni $\left(\mathrm{O}_{2}^{-\bullet}\right)$ radikali koji dalje oksidiraju organsku molekulu onečišćenja. Modificiranjem uvjeta sinteze pripremljeni su PPy/TiO 2 kompozitni fotokatalizatori sintetizirani u trajanju od 90 i 270 min te je ispitana njihova fotokatalitička djelotvornost prilikom razgradnje bojila Reactive Red 45 (RR 45), slika $5 .{ }^{9}$

Rezultati su pokazali da produljeno vrijeme sinteze i veća količina polipirola odgovarajuće molekulske strukture u nanokompozitu pridonosi većoj učinkovitosti fotokatalizatora. Međutim to ne znači da će daljnje produljenje vremena sinteze povećati fotokatalitičku djelotvornost kompozita. Povećanje koncentracije polipirola tijekom sinteze, odnosno priprema uzorka s debljim slojem polipirola od monomolekulskog, mogla bi negativno djelovati na fotokatalitičku aktivnost jer vodljivi polimer ne bi bio u bliskom kontaktu s površinom $\mathrm{TiO}_{2}$ fotokatalizatora. U tom slučaju, apsorpcija fotona te prijenos elektrona iz vodljive vrpce polimera na $\mathrm{TiO}_{2}$ bio bi otežan, a njegova fotokatalitička djelotvornost bila bi smanjena. Može se zaključiti da fotokatalitička aktivnost znatno ovisi o koncentraciji vodljivog polimera, a njegova svojstva ponajprije ovise o stupnju oksidacije tijekom sinteze, omjeru monomera i oksidansa, vrsti oksidansa kao i temperaturi sinteze.

\subsection{Polimerni nanokompoziti smanjene gorivosti}

Sintetski polimeri pri povišenim temperaturama, uobičajeno iznad $300{ }^{\circ} \mathrm{C}$ podložni su nagloj razgradnji uz nastajanje niskomolekulnih plinovitih produkata koji su u mješavini sa zrakom zapaljivi. Takvo ponašanje im ograničava primjenu u mnogim područjima, poput građevinarstva, zrakoplovnoj industriji, brodogradnji, u električnim i elektroničkim uređajima. Iz tog razloga polimeri se modificiraju kako bi se dobio materijal smanjenog stupnja gorivosti u odnosu na temeljni polimer, a to se postiže dodatkom aditiva koji se nazivaju usporivači gorenja. Prvi uspješni usporivači go- 
renja za polimere bili su spojevi s halogenim elementima, uglavnom broma i klora. ${ }^{12}$ Međutim, njihova upotreba se sve više izbjegava ili u potpunosti zabranjuje jer prilikom gorenja takva plastika otpušta otrovne dioksine i dibenzofurane, pa je potrebno njezino odvojeno prikupljanje i zbrinjavanje. ${ }^{13} \mathrm{Iz}$ tog razloga provode se istraživanja kako bi se pronašle "zelenije", a s druge strane jednako efikasne alternative. Kao potencijalne zamjene pokazali su se usporivači gorenja na osnovi metalnih hidroksida i fosfora koji efikasno smanjuju gorivost velikog broja polimera, posebno kada se kombiniraju s nanopunilima. ${ }^{14}$ Istraživanja su se prvotno provodila na polistirenu visoke žilavosti (PS-HI) uz dodatak različitih usporivača gorenja i nanopunila kroz nekoliko serija uzoraka, pri čemu je sastav odabranih uzoraka prikazan u tablici 3. Kao komercijalni usporivači gorenja upotrijebljeni su amonijev polifosfat (Exolit ${ }^{\circledR}$ AP766) i organski fosfinat (Exolit ${ }^{\circledR}$ OP1312) a kao nanopunila upotrijebljeni su metakrilsilanom modificiran silicijev dioksid $\left(\mathrm{SiO}_{2}\right)$ i prirodna montmorilonitna glina (MMT) modificirana s kvartarnom amonijevom soli. Svi uzorci pripremljeni su umješavanjem u dvopužnom ekstruderu.

Tablica 3 - Sastav PS-HI nanokompozita

Table 3 - Composition of PS-HI nanocomposites

\begin{tabular}{c|c|c|c|c|c|}
\hline \multirow{2}{*}{ Uzorak } & PS-HI & AP766 & OP1312 & $\mathrm{SiO}_{2}$ & MMT \\
\cline { 2 - 6 } & \multicolumn{5}{|c|}{ mas. $\%$} \\
\hline PS-4A-20AP & 76 & 20 & - & 4 & - \\
\hline PS-4A-20OP & 76 & - & 20 & 4 & - \\
\hline PS-AP-4MMT & 76 & 20 & - & - & 4 \\
\hline
\end{tabular}

Rezultati mjerenja toplinske stabilnosti termogravimetrijskom analizom (TGA) PS-HI (nano)kompozita prikazani su u tablici 4 a dane su vrijednosti temperature početka razgradnje $\left(T_{95}\right)$, temperature pri maksimalnoj brzini razgradnje $\left(T_{\max }\right)$, maksimalne brzine razgradnje $\left(r_{\max }\right)$ i ugljeniziranog ostatka pri $550{ }^{\circ} \mathrm{C}$. Vidljivo je da kod svih uzoraka koji sadrže usporivače gorenja dolazi do znatnog sniženja $T_{95}$, u nekim slučajevima i preko $100{ }^{\circ} \mathrm{C}$, što ukazuje na raniji početak razgradnje u odnosu na čisti PS-HI. Takvo ponašanje je i očekivano jer da bi usporivači gorenja bili efikasni, njihova razgradnja treba započeti prije razgradnje polimerne matrice. $\mathrm{S}$ druge strane vidljiv je porast $T_{\max } \mathrm{i}$ smanjenje $r_{\max }$ što ukazuje na to da se sintetiziranim uzor- cima maksimalna brzina razgradnje pomiče na više temperature, a istodobno se sama brzina smanjuje u usporedbi s čistim polimerom. Također, vidljiv je znatan porast ostatne mase na kraju pirolize koja raste s 1,1\% koliko ima PS-HI do čak 20,0 \% kod uzorka koji sadrži usporivač gorenja Exolit AP766 kombiniran s montmorilonitnom glinom. Takav porast toplinske stabilnosti sintetiziranih uzoraka pozitivno se odrazio i na smanjenje njihove gorivosti, što se vidi iz rezultata testa graničnog indeksa kisika (LOI); tablica 4. Čisti PS-HI ima LOI vrijednost $18 \% \mathrm{O}_{2}$, što znači da lako i brzo gori na zraku koji sadrži $21 \% \mathrm{O}_{2}$. Svim sintetiziranim uzorcima LOI iznosi od 22 pa čak do $27 \% \mathrm{O}_{2}$, što ukazuje na to da ti uzorci pokazuju značajno povećanu otpornost na gorenje jer je potrebna povećana količina kisika kako bi se zapalili i gorili.

Kako učinkovitost punila općenito, pa tako i usporivača gorenja ovisi u dispergiranosti unutar polimerne matrice, snimljena je morfologija pretražnim i transmisijskim elektronskim mikroskopom (SEM i TEM) a snimke su za odabrane uzorke prikazane na slici 6. Uz snimke sa SEM-a (6a-6b) prikazani su i rezultati EDX mapiranja karakterističnih elemenata. Silicij potječe iz $\mathrm{SiO}_{2}$ nanopunila, dok su izvor fosfora usporivači gorenja AP766 i OP1312 koji su po svojoj strukturi amonijev polifosfat, odnosno organski fosfinat. Vidljivo je da je kod svih uzoraka disperzija punila relativno homogena bez izraženog agregiranja čestica što je vrlo česta pojava kod nanopunila poput $\mathrm{SiO}_{2}$. Tome je svakako doprinijela i površinska obrada silicijeva dioksida metakril silanima u svrhu poboljšanja mješljivosti s polimernom matricom. Na slici 6c) prikazana je TEM snimka uzorka kojemu je kao nanopunilo dodana montmorilonitna glina. Vidljivo je da je došlo do razdvajanja slojeva nanogline,

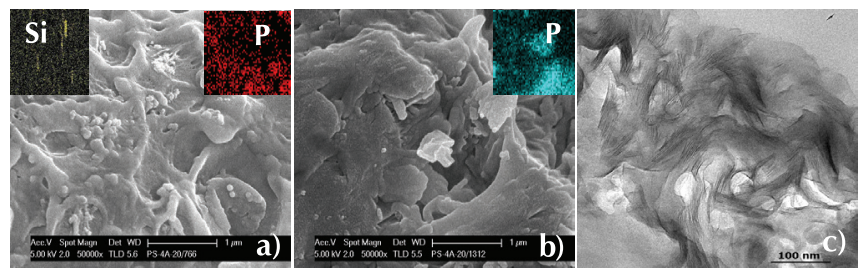

Slika 6 - SEM slike uzoraka: a) PS-4A-20AP i mapiranje Si i P, b) PS-4A-20OP i mapiranje P; c) TEM slika uzorka PS-AP4MMT

Fig. 6 - SEM pictures of samples: a) PS-4A-20AP and mapping of Si and P, b) PS-4A-20OP and mapping of P; c) TEM picture of sample PS-AP-4MMT

Tablica 4 - TGA i LOI podatci za PS-HI nanokompozite

Table 4 - TGA and LOI data of PS-HI nanocomposites

\begin{tabular}{c|c|c|c|c|c}
\hline Uzorak & $T_{95} /{ }^{\circ} \mathrm{C}$ & $T_{\max } /{ }^{\circ} \mathrm{C}$ & $r_{\max } / \% \min ^{-1}$ & Ostatak $/ \%$ & $\mathrm{LOI} \% \mathrm{O}_{2}$ \\
\hline PS & 374 & 418 & 14,0 & 1,1 & 18 \\
\hline PS-4A-20AP & 337 & 431 & 9,2 & 12,4 & 22 \\
\hline PS-4A-20OP & 323 & 416 & 10,7 & 7,6 & 27 \\
\hline PS-AP-4MMT & 258 & 420 & 8,2 & 20,0 & 25 \\
\hline
\end{tabular}


što ukazuje na interkalaciju polimernih molekula između slojeva, čime nastaje prava nanostruktura, a moguće je primijetiti i poneki potpuno odvojeni, delaminirani sloj. Sa slike je moguće procijeniti razmak slojeva, te on iznosi od 3 do 3,5 nm, što je povećanje razmaka od 10 do $25 \%$ u odnosu na čistu glinu. Vidljivo je također da su prisutne sve tri vrste struktura, od nemješljive do eksfolirane, ali da je interkalirana dominantna.

Utjecaj dodatka punila na mehanička svojstva polimera određen je mjerenjem prekidne čvrstoće (s) i prekidnog istezanja (e) a rezultati su dani u tablici 5 . Vidljivo je da dodatak usporivača gorenja uglavnom nema negativan utjecaj na prekidnu čvrstoću PS-HI a u nekim slučajevima dolazi i do povećanja čvrstoće od oko $20 \%$. S druge strane, primjetno je da se dodatak punila negativno odrazio na istezljivost uzoraka, koja je pala od 40 do $80 \%$.

Tablica 5 - Prekidna čvrstoća i prekidno istezanje PS-HI nanokompozita

Table 5 - Tensile strength and elongation at break of PS-HI nanocomposites

\begin{tabular}{c|c|c}
\hline Uzorak & $s / \mathrm{N} \mathrm{mm}^{-2}$ & $\mathrm{e} / \%$ \\
\hline PS & $18,7 \pm 0,6$ & $63,9 \pm 10,5$ \\
\hline PS-4A-20AP & $18,2 \pm 1,7$ & $37,2 \pm 6,2$ \\
\hline PS-4A-20OP & $17,6 \pm 0,6$ & $10,4 \pm 5,3$ \\
\hline PS-AP-4MMT & $22,0 \pm 1,5$ & $25,7 \pm 3,8$ \\
\hline
\end{tabular}

Znanja o gorivosti materijala stečena na ispitivanju PS-HI kasnije su iskorištena na ispitivanju gorivosti drvno-plastičnih kompozita (WPC). To su materijali u kojima je polimerni materijal matrica a drvni materijal u obliku brašna ili vlakana dispergiran kao punilo. Kombinirajući svojstva drva i plastike, WPC je našao primjenu za proizvodnju različitih proizvoda kao što su podovi, okviri prozora, ograde, elementi u autoindustriji i kućanstvu radi čega je bitno da ima nisku gorivost. Istraživanja su se provodila na kompozitima s polimernom matricom koja je mješavina polietilena visoke gustoće (PE-HD) i poli(vinil-klorida) (PVC) u masenom omjeru 70 : 30 uz dodatak 20 phr drvnog brašna i nanopunila kalcijeva karbonata $\left(\mathrm{CaCO}_{3}\right)$ ili silicijeva dioksida $\left(\mathrm{SiO}_{2}\right)$. Kao usporivač gorenja upotrijebljen je amonijev polifosfat (Exolit ${ }^{\circledR}$ AP766) uz dodatak pentaeritritola (PER) koji u kombinaciji čine intumescentni sustav. ${ }^{15}$ Svi uzorci su pripremljeni umješavanjem $u$ dvopužnom ekstruderu a točan sastav dan je u tablici 6 . Toplinska stabilnost ispitana je s TGA, gorivost vertikalnim UL-94 testom te su određena mehanička svojstva i stupanj bubrenja u vodi.

Tablica 6 - Sastav uzoraka drvno-plastičnih nanokompozita Table 6 - Composition of wood-plastic nanocomposite samples

\begin{tabular}{c|c|c|c|c|c|c}
\hline Uzorak & PE-HD/PVC & DB & $\mathrm{CaCO}_{3}$ & $\mathrm{SiO}_{2}$ & PER & AP766 \\
\hline & mas. $\%$ & \multicolumn{5}{|c}{ phr } \\
\hline WPC1 & $70 / 30$ & 20 & - & - & - & - \\
\hline WPC2 & $70 / 30$ & 20 & - & - & - & 20 \\
\hline WPC3 & $70 / 30$ & 20 & - & - & 7 & 20 \\
\hline WPC4 & $70 / 30$ & 20 & - & 3 & 7 & 20 \\
\hline WPC5 & $70 / 30$ & 20 & 3 & - & 7 & 20 \\
\hline
\end{tabular}

Iz tablice 7 vidljivo je da svi uzorci imaju relativno nisku temperaturu početka razgradnje $T_{95}$, između 170 i $240{ }^{\circ} \mathrm{C}$ jer na tim temperaturama već započinje razgradnja hemiceluloze, lignina i celuloze iz drvne komponente. Vidljivo je da svi uzorci imaju nižu $T_{95}$ u odnosu na WPC1 koji ne sadrži usporivače gorenja jer uz drvne komponente dolazi i do početka razgradnje AP usporivača gorenja. Efekt usporivača gorenja na toplinsku stabilnost vidljiv je u smanjenju maksimalne brzine razgradnje u odnosu na uzorak WPC1 te na znatno povećanje ugljeniziranog ostatka nakon pirolize. Posebno izražen porast vidljiv je kod uzoraka WPC3-5 koji uz AP usporivač gorenje sadrže i PER, pa ostatak raste gotovo dvostruko u odnosu na WPC1. Tako WPC1 ima ostatak 15,5\%, WPC2 19,3\%, dok ostali uzorci imaju od 24 do $28 \%$.

Takav porast količine ostatka ukazuje na stvaranje zaštitnog sloja na površini polimera koji stvara toplinsku izolaciju i štiti ostatak polimera prilikom gorenja. To je potvrđeno UL-94 testom (tablica 7) gdje uzorci WPC1 (bez usporivača) i WPC2 (samo AP usporivač, bez PER-a) već nakon prvog paljenja gore više od $50 \mathrm{~s}$ i time padaju na testu. Uzorci WPC3-4 su se gasili u manje od 5 s nakon svake primjene plamena i time postigli najvišu V-0 kategoriju na testu, dok

Tablica 7 - TGA i UL-94 rezultati za uzorke drvno-plastičnih nanokompozita Table 7 - TGA and UL-94 results for wood-plastic nanocomposite samples

\begin{tabular}{c|c|c|c|c|c|c|c}
\hline \multirow{2}{*}{ Uzorak } & \multicolumn{6}{|c|}{ TGA } & \multicolumn{3}{c}{ UL-94 } \\
\cline { 2 - 8 } & $T_{95} /{ }^{\circ} \mathrm{C}$ & $T_{\max } /{ }^{\circ} \mathrm{C}$ & $r_{\max } / \% \min ^{-1}$ & Ostatak $\%$ & 1. paljenje & 2. paljenje & UL-94 \\
\hline WPC1 & 239 & 450 & 8,1 & 15,5 & $>50 \mathrm{~s}$ & - & - \\
\hline WPC2 & 222 & 442 & 6,5 & 19,3 & $>50 \mathrm{~s}$ & - & - \\
\hline WPC3 & 191 & 447 & 6,4 & 28,5 & 2,6 & 1,4 & V-0 \\
\hline WPC4 & 210 & 448 & 7,9 & 24,1 & 1,8 & 1,4 & V-0 \\
\hline WPC5 & 187 & 450 & 7,2 & 24,3 & 1,6 & $>50 \mathrm{~s}$ & - \\
\hline
\end{tabular}



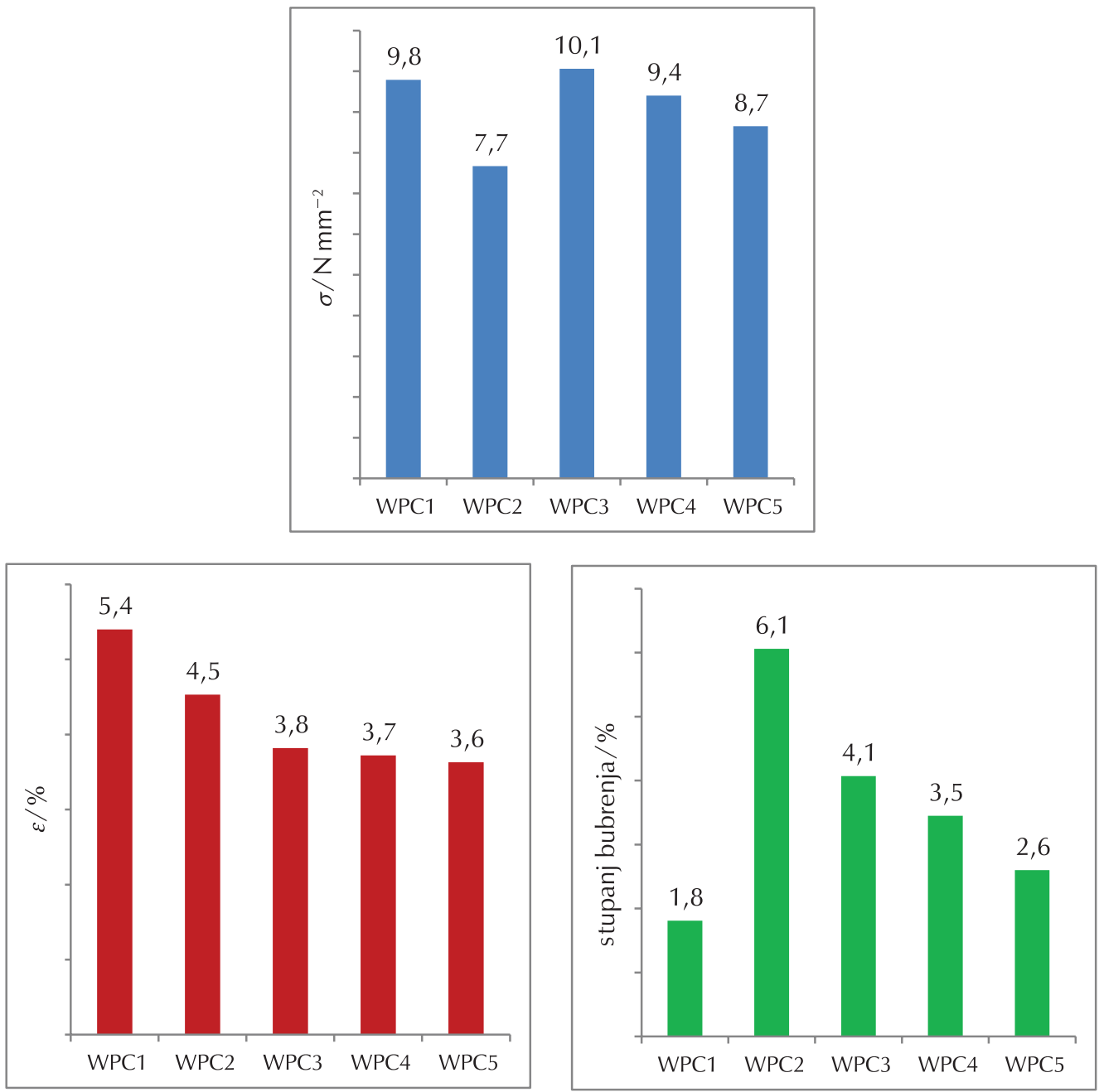

Slika 7 - a) prekidna čvrstoća, b) prekidno istezanje i c) stupanj bubrenja ispitivanih uzoraka drvno-plastičnih nanokompozita

Fig. 7 -a) tensile strength, b) elongation, and c) degree of swelling of the tested specimens of wood-plastic nanocomposites

je uzorak WPC5 također pao na testu, ali tek nakon druge primjene plamena. Taj je uzorak kao napunilo sadržavao $\mathrm{CaCO}_{3}$ za razliku od $\mathrm{SiO}_{2}$ u uzorcima koji su dobili V-0 kategoriju. $\mathrm{SiO}_{2} \mathrm{~s}$ AP/PER kombinacijom stvara silikofosfatni sloj nalik keramici koji dodatno stabilizira ugljenizirani sloj što osigurava dodatni izolacijski sloj na površini kompozita i time osigurava visoku otpornost na gorenje. ${ }^{16} \mathrm{~S}$ druge strane, kod $\mathrm{CaCO}_{3}$ ne dolazi do takve pojave, te zbog toga kod tog uzorka nakon druge primjene plamena dolazi do razaranja zaštitnog sloja na površini zbog čega ne dolazi do samogašenja uzorka.

Rezultati prekidne čvrstoće (slika 7a) pokazuju kod uzorka WPC2 dolazi do primjetnog pada čvrstoće, ali da primjenom AP/PER kombinacije usporivača (WPC3) dolazi čak i do manjeg porasta u odnosu na WPC1 uzorak, dok je uz dodatak nanopunila vidljiv ponovo manji pad. Prekidno istezanje (slika 7b) pada kod svih uzoraka koji sadrže usporivače gorenja.
Kako se drvno-plastični kompoziti često upotrebljavaju u vanjskim uvjetima gdje su izloženi vlazi, ispitan je stupanj bubrenja u vodi (slika 7c) te se pokazalo da dodatkom usporivača gorenja dolazi do porasta stupnja bubrenja jer uzorak WPC1 bubri 1,8 \%, dok svi ostali uzorci bubre između 2,6 i 6,1\%, što je i dalje prihvatljiva vrijednost jer obrađeno drvo bubri i preko $10 \% .^{17}$

\section{Zaključak}

Iz danih primjera specifične primjene polimernih materijala i dobivenih rezultata može se zaključiti da su uspješno primijenjene tehnike modifikacije budući da je došlo do razvoja specifičnih, točno željenih svojstva polimernih nanokompozita. Tako, iz rezultata za PVC nanokompozite vidljivo je povećano antimikrobno djelovanje, tj. usporeni rast mikroorganizama, za uzorak s višim sadržajem srebro- 
va nitrata. Zatim, iznimno dobro UV blokiranje i zaštitu od UV zračenja pokazuje uzorak s povećanim sadržajem srebrova nitrata, a ujedno uzorcima nisu narušena mehanička svojstva. Iz rezultata danih za ocjenu fotokatalitičke aktivnost polimernih nanokompozitnih fotokatalizatora, može se zaključiti, da je znatno povećana u području vidljivog dijela spektra u odnosu na čisti $\mathrm{TiO}_{2}$. Time je dokazano njihovo prošireno djelovanje jer su aktivirani u vidljivom dijelu spektra. $U$ istraživanjima gorivosti i toplinske stabilnosti PS-HI i WPC nanokompozita postignuto je znatno povećanje stupnja otpornosti na gorenje optimalnom kombinacijom usporivača gorenja i nanopunila bez negativnog ili čak i uz pozitivan utjecaj na prekidnu čvrstoću materijala. Stoga, može se zaključiti da napredni polimerni materijali svakim danom nalaze nove primjene koje omogućuju razvoj novih tehnologija i društva u cjelini.

\section{ZAHVALA}

Prikazana istraživanja provedena su u sklopu znanstvenih istraživačkih projekta: Potpora istraživanju, "PVC nanokompoziti s UV zaštitnim svojstvima" (TP1.29), Sveučilište u Zagrebu, 2014.; "Razvoj fotokatalitičkih polimernih nanokompozita za pročišćavanje otpadnih voda" DePoNPhoto, (IP-11-2013-5092), HRZZ, 2014. - 2018; "Istraživanje, razvoj i ocjena polimernih kompozita za primjenu u građevinarstvu" (125-0821504-1976), MZOS, 2007. - 2013.

\section{Popis kratica i simbola List of abbreviations and symbols}

\begin{tabular}{|c|c|}
\hline A & $\begin{array}{l}\text { - apsorbancija } \\
\text { - absorbance }\end{array}$ \\
\hline $\mathrm{AgNO}_{3}$ & $\begin{array}{l}\text { - srebrov nitrat } \\
\text { - silver nitrate }\end{array}$ \\
\hline C & 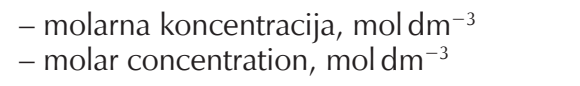 \\
\hline$C_{0}$ & $\begin{array}{l}\text { - koncentracija boje na početku } \\
\text { - starting dye concentration }\end{array}$ \\
\hline$C_{\mathrm{t}}$ & $\begin{array}{l}\text { - koncentracija boje nakon } \\
\text { određenog vremena reakcije fotokatalize } \\
\text { - dye concentration after } \\
\text { certain time of photocatalysis }\end{array}$ \\
\hline $\mathrm{Cu}\left(\mathrm{NO}_{3}\right)_{2}$ & $\begin{array}{l}\text { - bakrov nitrat } \\
\text { - copper nitrate }\end{array}$ \\
\hline DNA & $\begin{array}{l}\text { - deoksiribonukleinska kiselina } \\
\text { - deoxyribonucleic acid }\end{array}$ \\
\hline
\end{tabular}

dTG - derivirana termogravimetrijska krivulja - derivate thermogravimetric curve

$\mathrm{e}^{-} \quad-$ elektron

- electron

$\mathrm{h}^{+} \quad-$ šupljina

- hole

$\mathrm{O}_{2}^{\cdot-} \quad-$ superoksidni radikal

- superoxide radical

$\mathrm{OH}^{\bullet} \quad$ - hidroksilni radikal

- hydroxyl radical

PANI - polianilin

- polyaniline

PEDOT - poli(3,4-etilendioksitiofen)

- poly(3,4-ethylenedioxythiophene)

PPy - polipirol

- polypyrrole

PVC - poly(vinil klorid)

- poly(vinyl chloride)

RR45 - Reactive Red 45

- Reactive Red 45

SEM - pretražna elektronska mikroskopija

- scanning electron microscopy

- vrijeme, min

- time, $\min$

- temperatura, ${ }^{\circ} \mathrm{C}$

- temperature, ${ }^{\circ} \mathrm{C}$

TG - termogravimetrijska krivulja

- thermogravimetric curve

$T_{95} \quad-$ temperatura pri kojoj uzorak izgubi $5 \%$ početne mase, ${ }^{\circ} \mathrm{C}$

- temperature where $5 \%$ of starting mass is lost, ${ }^{\circ} \mathrm{C}$

$T_{\max } \quad$ - temperatura pri maksimalnoj brzini razgradnje, ${ }^{\circ} \mathrm{C}$

- temperature at maximum degradation rate, ${ }^{\circ} \mathrm{C}$

UV $\quad-$ ultraljubičasto zračenje

- ultraviolet irradiation

Vis $\quad-$ vidljivo zračenje

- visible irradiation

- valna duljina

- wave length

- masena koncentracija RR45 bojila, $\mathrm{mg} \mathrm{I}^{-1}$

- mass concentration of RR45 dye, $\mathrm{mgl}^{-1}$

$\gamma_{\text {kat }}-$ masena koncentracija katalizatora, $\mathrm{gl}^{-1}$

- mass concentration of catalyst, $\mathrm{g}^{-1}$

- prekidna čvrstoća, $\mathrm{Nmm}^{-2}$

- tensile strength, $\mathrm{Nmm}^{-2}$

- prekidno istezanje, $\%$

- elongation at break, \% 


\section{Literatura \\ References}

1. Lj. Kratofil Krehula, A. Papić, S. Krehula, V. Gilja, L. Foglar, Z. Hrnjak-Murgić, Properties of UV protective films of poly(vinylchloride)/ $\mathrm{TiO}_{2}$ nanocomposites for food packaging, Polym. Bull. 74 (2017) 1387-1404, doi: https://doi. org/10.1007/s00289-016-1782-4

2. L. Guo, W. Yuan, Z. Lu, C. M. Li, Polymer/nanosilver composite coatings for antibacterial applications, Colloids Surf. A 439 (2013) 69-83, doi: https://doi.org/10.1016/j.colsurfa.2012.12.029

3. R. Dastjerdi, M. Montazer, A review on the application of inorganic nano-structured materials in the modification of textiles: focus on anti-microbial properties, Colloids Surf. B Biointerf. 79 (2010) 5-18, doi: https://doi.org/10.1016/j.colsurfb.2010.03.029

4. Z. Hrnjak-Murgić, A. Rešček, A. Ptiček Siročić, Lj. Kratofil Krehula, Z. Katančić, Nanoparticles in Active Polymer Food Packaging, Surrey: Smithers Pira, 2015.

5. R. J. Nussbaumer, R. Caseri, P. Smith, T. Tervoort, Polymer- $\mathrm{TiO}_{2}$ nanocomposites: a route towards visually transparent broadband UV filters and high refractive index materials, Macromol. Mater. Eng. 288 (2003) 44-49, doi: https://doi. org/10.1002/mame.200290032

6. K. D. Tapan, S. Prusty, Review on Conducting Polymers and Their Applications, Polym. Plast. Technol. Eng. 51 (2012) 1487-1500, doi: https://doi.org/10.1080/03602559.2012.7 10697

7. J. M. Herrmann, Heterogeneous photocatalysis: fundamentals and applications to the removal of various types of aqueous pollutants, Catal. Today 53 (1999) 115-129, doi: https:// doi.org/10.1016/S0920-5861(99)00107-8

8. M. Pelaez, N. Nolan, S.Pillai, M. Seery, P. Falaras, A. G. Kontos, P. S. M. Dunlop, J. W. J. Hamiltone, J. A. Byrne, K. O'Shea, M. H. Entezari, D. D. Dionysiou, A Review on the Visible Light Active Titanium Dioxide Photocatalysts for Environmental Applications, Appl. Catal. B-Environ. 125 (2012) 331-349, doi: https://doi.org/10.1016/j.apcatb.2012.05.036

9. Lj. Kratofil Krehula, J. Stjepanović, M. Perlog, S. Krehula, V. Gilja, Z. Hrnjak-Murgić, J. Travaš- Sejdić, Conducting poly- mer polypyrrole and titanium dioxide nanocomposites for photocatalysis of RR45 dye under visible light, Polymer Bull. 76 (2018) 1-19, doi: https://doi.org/10.1007/s00289-0182463-2.

10. V. Gilja, K. Novaković, J. Travaš-Sejdić, Z. Hrnjak-Murgić, M. Kraljić Roković, M. Žic, Stability and synergistic effect of polyaniline $/ \mathrm{TiO}_{2}$ photocatalysts in degradation of azo dye in wastewater, Nanomaterials 7 (2017) 1-12 (412), doi: https:// doi.org/10.3390/nano7120412.

11. X. W. Li, W. Chen, C. Q. Bian, J. B. He, N. Xu, G. Xue, Surface modification of $\mathrm{TiO}_{2}$ nanoparticles by polyaniline, Appl. Surf. Sci. 217 (2003) 16-22, doi: https://doi.org/10.1016/ S0169-4332(03)00565-8

12. R. Dumler, H. Thoma, D. Lenoir, O. Hutzinger, Thermal formation of polybrominated dibenzodioxins (PBDD) and dibenzofurans (PBDF) from bromine containing flame retardants, Chemosphere 19 (1989) 305-308, doi: https://doi. org/10.1016/0045-6535(89)90328-7.

13. Y. Wang, F.-S. Zhang, Degradation of brominated flame retardant in computer housing plastic by supercritical fluids, J. Hazard. Mater. 29 (2012) 153-163, doi: https://doi. org/10.1016/j.jhazmat.2011.12.055.

14. F. Laoutid, L. Bonnaud, M. Alexandre, J.-M. Lopez-Cuesta, Ph. Dubois, New Prospects in Flame Retardant Polymer Materials: From Fundamentals to Nanocomposites, Mat. Sci. Eng. R. 63 (2009) 100-125, doi: https://doi.org/10.1016/j. mser.2008.09.002.

15. S. Duquesne, S. Bourbigot, Char formation and characterization, u C. A. Wilkie i A. B. Morgan (ur.), Fire retardancy of polymeric materials, $2^{\text {nd }}$ Ed., CRC Press Taylor \& Francis Group, Boca Raton, 2010., str. 129-162.

16. S. Bourbigot, S. Duquesne, Intumescence and nanocomposites: A novel route for flame-retarding polymeric materials, u A. B. Morgan i C. A. Wilkie (ur.), Flame retardant polymer nanocomposites, Wiley Interscience, Hoboken, NJ, $2007 .$, str. 131-162.

17 J. Brauns, K. Rocens, Design of humidity sensitive wooden materials for multi-objective application, Wood Sci. Tech. 38 (2004) 311-321, doi: https://doi.org/10.1007/s00226-0040242-8. 


\section{SUMMARY}

\section{Applications of Advanced Polymer Materials}

Vanja Gilja, Zvonimir Katančić, Ljerka Kratofil Krehula, Ana Peršić, and Zlata Hrnjak-Murgić*

The intense development of advanced polymer materials, such as polymer blends and (nano) composites, offers a number of innovative solutions for different applications, which is of great economic importance for the plastics industry and the fields in which they are applied. Advanced polymer modification techniques have pushed the limit, and have significantly improved the cost/ properties ratio engendered by manipulating the structure of polymers. Blending dissimilar polymers, preparing composites where polymer matrix is modified by fillers, and creating multilayer structures and laminates are some of the most significant polymer modification techniques. In such modification, synergistic effects between the components are required in order to achieve excellent performances tailored to specific applications, such as antimicrobial activity, blocking ultraviolet light, reducing flammability, photocatalytic activity. This paper presents the results of the research on polymer nanocomposites aimed at the modification of the aforementioned properties.

\section{Keywords}

Advanced polymer materials, polymer (nano)composites, antimicrobial activity,

UV blockers, flame retardants, photocatalysts

Faculty of Chemical Engineering and

Technology, University of Zagreb

Review

Department of Polymer Engineering and

Organic Chemical Technology

Marulićev trg 19, HR-10000, Zagreb, Croatia

Received August 29, 2019 Accepted September 19, 2019 